Marquette University

e-Publications@Marquette

College of Education Faculty Research and

Publications

Education, College of

$6-2002$

\title{
Maternal Factors Related to Parenting Young Children with Congenital Heart Disease
}

Lynn K. Carey

Bonnie C. Nicholson

University of Southern Mississippi

Robert A. Fox

Marquette University, robert.fox@marquette.edu

Follow this and additional works at: https://epublications.marquette.edu/edu_fac

Part of the Education Commons

\section{Recommended Citation}

Carey, Lynn K.; Nicholson, Bonnie C.; and Fox, Robert A., "Maternal Factors Related to Parenting Young Children with Congenital Heart Disease" (2002). College of Education Faculty Research and Publications. 38.

https://epublications.marquette.edu/edu_fac/38 


\title{
Maternal Factors Related to Parenting Young Children with Congenital Heart Disease
}

\author{
Lynn K. Carey \\ Bonnie C. Nicholson \\ University of Southern Mississippi \\ Hattiesburg, MS \\ Robert A. Fox \\ Counselor Education and Counseling Psychology \\ Marquette University \\ Milwaukee, WI
}

\begin{abstract}
The purpose of this study was to compare the early child-rearing practices between mothers of young children with congenital heart disease (CHD) and mothers of healthy children. In addition, maternal stress, parental developmental expectations, and the early behavioral and emotional development of their children were explored. Maccoby's (1992) socialization theory emphasizing the reciprocal nature of mother-child interactions provided the framework for this study. Findings from quantitative self-report measures and videotaped parent-child interactions showed a remarkable similarity between mothers of children with CHD and mothers of healthy children. In contrast, qualitative data revealed important differences with mothers of CHD children reporting high levels of vigilance with their children. The important role of promoting the principle of normalization among mothers of children with CHD and ensuring a sufficient support system is discussed.
\end{abstract}

Journal of Pediatric Nursing, Vol. 17, No. 3 (June 2002): pg. 174-183. DOI. This article is C Elsevier (WB Saunders) and permission has been granted for this version to appear in e-Publications@Marquette. Elsevier (WB Saunders) does not grant permission for this article to be further copied/distributed or hosted elsewhere without the express permission from Elsevier (WB Saunders). 
Parents and other significant caregivers play an important role in children's development (Collins, Maccoby, Steinberg, Hetherington, $\&$ Bornstein, 2000). There are numerous factors that influence the quality of parenting that children receive (Belsky, 1990). The health status of a child, including the onset of a chronic illness, is one of many factors that can contribute to the quality of child rearing (Kazak, 1989). When considering that up to $30 \%$ of children have a chronic health condition (Newacheck \& Halfon, 1998), 11\% of whom are living with conditions considered moderate to severe (Newacheck, Stoddard, \& McManus, 1993), a significant number of families are faced with an even more challenging future than they had anticipated. How parents respond to this situation can affect both the short- and long-term developmental outcomes for their children.

\section{Conceptual Model}

The family context is an important contributing factor in the socialization of children (Maccoby \& Martin, 1983). More specifically, the role of parents in influencing their children's outcomes has increasingly been the focus of research. What has emerged is the general finding that parents and children influence each other in a reciprocal manner (Maccoby, 1992). For example, children who have difficult temperaments are likely to bring out different responses in their parents than children who are more easy-going. Similarly, children born with significant health impairments may also elicit unique parental responses (e.g., overprotective). How parents respond over time can influence the children's short- and long-term developmental outcomes. In general, an authoritative parenting style (i.e., parents who are responsive to their children's needs and set reasonable limits on their behavior) produces the most favorable childhood outcomes (Steinberg, Lamborn, Darling, Mounts, \& Dornbusch, 1994).

There are multiple determinants that impact parenting practices (Belsky, 1990), including socioeconomic and maternal factors. For example, Fox, Platz, and Bentley (1995) reported less favorable parenting practices among mothers who were younger, single, from lower income and educational levels, and who had more than one child living at home. Numerous other factors including marital satisfaction, level of spousal support, and the mental health of the parent can

Journal of Pediatric Nursing, Vol. 17, No. 3 (June 2002): pg. 174-183. DOI. This article is @ Elsevier (WB Saunders) and permission has been granted for this version to appear in e-Publications@ Marquette. Elsevier (WB Saunders) does not grant permission for this article to be further copied/distributed or hosted elsewhere without the express permission from Elsevier (WB Saunders). 
influence childrearing practices (Simons, Beamon, Conger, \& Chao, 1993). In addition, the child's unique characteristics, including temperament (O'Conner, Deater-Deckard, Fulker, Rutter, \& Plomin, 1998) and health status (Dolgin, Phipps, \& Harrow, 1990) also influence parenting practices. Regarding the rearing of chronically ill children, Maccoby's (1992) model would predict that parents may significantly alter their child-rearing patterns to accommodate these children's special needs. In fact, Van Dongen-Melmen and SandersWoudstra (1986) suggested that it would be difficult to imagine parents who would not be at least somewhat overly protective of their children. This overprotective parenting style, fueled at least in part by parental anxiety, could hamper the overall development of these children (Utens et al., 1994).

\section{Purpose}

The purpose of this study was to compare the early child-rearing practices between mothers of children with congenital heart disease (CHD) and mothers of healthy children. In addition, parenting stress, parental expectations of their young children, and the early behavioral and emotional development of toddlers and preschoolers were explored.

\section{Review of the Literature}

Parents often respond with shock and disbelief when a diagnosis of a chronic illness in their child is first made (Sabbeth, 1984). Parenting a child with a chronic illness has been considered to be a highly stressful, demanding experience for the parents and family (Austin, 1991). However, positive adaptation and growth has also been reported among these families (Clawson, 1996).

Most available studies regarding the parenting of children with CHD have emphasized parental adjustment to the diagnosis (Emery, 1989), the demands and related stress that these children place on the family (Svavarstottir \& McCubbin, 1996), and early care-giving issues, particularly infant feeding difficulties (Lobo, 1992). Relatively less attention has been devoted to the emotional adjustment of these children (DeMaso, Beardslee, Silbert, \& Fyler, 1991). Goldberg, 
Simmons, Newman, Campbell, and Fowler (1991) studied motherinfant interactions in mothers of children with CHD and mothers of healthy children. Maternal-child attachments in the CHD group were less secure than attachments in the healthy group. In the CHD group, securely attached infants showed greater improvement in their physical health than those infants who were less securely attached. DeMaso, et al. (1990) found that the behavioral adjustment of children with CHD was significantly related to the level of parenting stress.

With recent medical advances significantly improving the prognosis for children with CHD (Marino \& Lipshitz, 1991), the concept of normalization (Krulik, 1980) has been extended to these families. Normalization is described as "the constant process of actively accommodating the changing physical and emotional needs of the child" (Deatrick, Knafl, \& Walsh, 1988, p. 17). To accomplish normalization in families of children with chronic illnesses, health care professionals commonly advise these parents to raise their children as close to normal as possible (Deatrick, Knafl, \& Murphy-Moore, 1999). This normalization philosophy is intended to minimize the impact of a chronic health condition and optimize the child's normative development while fostering a greater acceptance of the child with a chronic illness within society (Holaday, 1984).

\section{Methodology}

Two groups of mothers with children between 2 and 5 years of age from a large urban area in the Midwest made up the study sample. The first group included mothers of children with moderate to severe $\mathrm{CHD}$, recruited through a large pediatric cardiology clinic at a children's hospital. Cardiac severity was rated by each child's pediatric cardiologist using the Cardiologist's Perception of Medical Severity (DeMaso, et al., 1991), which has a rating scale ranging from $1=$ insignificant (disorder has no impact on child's health) to $5=$ severe (uncorrectable lesion or only complex, palliative repair possible), and an inter-rater reliability of .97. Five pediatric cardiologists participated in this study. Subjects in the CHD group required a severity rating of at least moderate ( 3 or higher) to be included in this study. The second group included mothers of healthy children (absence of chronic illnesses, significant health conditions, or birth anomalies) who were 
recruited from pediatric medical practices and school settings and matched with the first group on the child's age and gender and maternal marital and socioeconomic status.

Subjects who met the inclusion criteria were visited in their homes by the first author who reviewed the study procedures and obtained written informed consent. The home visits averaged about 1.5 hours in length. Mothers received $\$ 50$ for participating and their children were given a toy or book.

An adapted family form, piloted in previous research (Nicholson, Anderson, Fox, \& Brenner, in press), was used to obtain family demographic information and to seek maternal responses to questions regarding how parenting was different than expected, whether or not they had attended parenting classes or sought professional help for their child's behavior, and the amount of social support they received for parenting. Next, the child and mother were videotaped playing together with a standard set of safe and age appropriate toys. A behavioral observational system adapted from the Dyadic Parent-Child Interaction Coding System (DPCICS; Eyberg, Robinson, Kniskern, \& O'Brien, 1978) was followed to structure the videotaping and code the mothers' and children's behaviors. For the first 5 minutes of the videotaped session, the mother was directed to let the child choose an activity and play with the child according to his or her rules. The mother was then directed to choose an activity and play with the child for the next 5 minutes according to the mother's rules. Finally, the mother was instructed to have the child help in cleaning up the play area.

After the videotaping, the instruments described below were administered. The Parent Behavior Checklist (PBC; Fox, 1994) is a 100 -item rating scale developed to measure parenting behaviors and parental expectations of young children between the ages of 1 year and 4 years, 11 months. Normed on an urban population of 1,056 mothers, the PBC measures parenting behaviors on three subscales: (1) discipline measures parental responses to children's challenging behaviors (e.g., "When my child has a temper tantrum, I spank him or her"), (2) nurturing measures specific positive parent behaviors that promote a child's psychological growth (e.g., "I praise my child for 
learning new things"), and (3) expectations measures parents' developmental expectations (e.g., "My child should be old enough to share toys"). More effective parenting strategies are associated with lower scores on discipline, higher scores on nurturing, and mid-range scores on expectations. Internal consistencies and test-retest reliabilities for each subscale, respectively, are as follows: discipline $=$ $.92, .87$; nurturing $=.91, .81$; and expectations $=.97, .98$. The PBC was selected for this study to assess the parental expectations and reported parenting practices of the families of children with CHD.

The Parenting Stress Index-Short Form (PSI) is a 36-item, selfreport measure of the amount of stress experienced by parents of young children (Abidin, 1995). The PSI measures parenting stress on three subscales: (1) parent distress measures the amount of distress a parent is experiencing in his or her role as a parent or as a function of personal factors that are related to parenting; (2) parent-child dysfunctional interaction measures the parent's perception that his or her child does not meet the parent's expectations and the interactions with his or her child are not reinforcing; and (3) difficult child measures the basic behavioral characteristics of children that make them either easy or difficult to manage. High scores on any of these subscales are indicative of an increased level of parental stress. Testretest and alpha reliabilities for the PSI total score are .84 and .91, respectively. This measure was selected to detect potential parental stress related to rearing a child with $\mathrm{CHD}$. The Eyberg Child Behavior Inventory (ECBI; Eyberg \& Ross, 1978) is a 36-item inventory that measures behavior problems common to children 2 to 16 years old. An intensity score is determined through the rating of the frequency of each behavior on a scale from 1 (never occurs) to 7 (always occurs). A problem score is determined by having respondents identify each behavior as a current problem with a "yes" or "no" response. The ECBI discriminates between problem and nonproblem children (Robinson, Eyberg, \& Ross, 1980). Reliabilities of this scale range from .86 (testretest) to .98 (internal consistency). The Behavior Screening Questionnaire (BSQ; Richman \& Graham, 1971) is a screening tool used to identify behavioral and emotional problems in preschool children. Inter-rater reliabilities are reported between .77 and .94. A correlation of . 88 between the BSQ and clinical rating of 3-year-old children has been reported. For the purposes of this study, the BSQ 
was adapted to include 12 behavior problem categories common among young children such as sleeping, toileting, and tantrums. New items also were added that assessed prosocial behaviors such as child helps clean up messes, is affectionate, and imitates others. The ECBI and BSQ were selected for this study to assess the present level of behavioral development of children with CHD.

\section{Results}

A total of 39 prospective mothers of children with CHD met the study's criteria and could be contacted by phone or mail. Mothers were contacted consecutively until a sample size of 30 was reached. Six subjects could not participate due to personal reasons (e.g., moving, caring for a seriously ill parent). The sample of 30 mothers of healthy children was matched with the CHD sample based on the children's age and gender and maternal marital and socioeconomic status.

For the CHD group, children's mean age was 3.44 years ( $S D=$ $0.93)$, mothers' mean age was 33.5 years $(S D=4.45)$, and the family included an average of 2.03 children (range $=1-5$ ). For the healthy group, children's mean age was 3.43 years $(S D=0.94)$, mothers' mean age was 32.13 years $(S D=4.16)$, and the family included an average of 2.20 children (range $=1-4$ ). Additional demographic data for both study groups are shown in Table 1 . Chi-square analyses found a significant difference between the groups on maternal employment ( $p=.045$ ) with more mothers of children with CHD as full-time homemakers $(36.7 \%)$ than mothers of healthy children $(16.7 \%)$.

Analyses of additional demographic variables including maternal age, child age, child gender, number of children in the family, and mother's and father's number of hours working outside of the home, family socioeconomic status (based on main wage earner's occupation), and maternal marital status showed no differences between groups (all $p>.05)$. There was a trend $(p<.058)$ for mothers of children with $\mathrm{CHD}$ to report higher levels of social support for their parenting (76.7\%) compared to mothers of healthy children $(53.3 \%)$. None of the families had sought professional help for their children's behavior. Additional characteristics of the CHD sample are shown in Table 2.

Journal of Pediatric Nursing, Vol. 17, No. 3 (June 2002): pg. 174-183. DOI. This article is @ Elsevier (WB Saunders) and permission has been granted for this version to appear in e-Publications@ Marquette. Elsevier (WB Saunders) does not grant permission for this article to be further copied/distributed or hosted elsewhere without the express permission from Elsevier (WB Saunders). 
For the CHD group, all of the children had been diagnosed by nine months of age, with most diagnosed within the first month of life $(86.7 \%)$. Tetralogy of Fallot was the most common diagnosis $(n=6)$, followed by hypoplastic left heart syndrome $(n=4)$ and aortic stenosis $(n=2)$; the remaining diagnoses were unique to particular children in the sample (e.g., bicuspid aortic valve and mild aortic stenosis; tricuspid atresia; ventricular septal defect). Of the sample, $46.7 \%$ were taking cardiac medications, although none of the children's activities were restricted at the time of this study.

\section{Self-Report Parenting and Child Behavior Measures}

A series of analyses were computed with group assignment as the independent variable (CHD, healthy) and the scores on the selfreport measures as the dependent variables. Scores that were conceptually related were analyzed together using multivariate analyses of variance (MANOVA); other scores were analyzed using one-way, analyses of variance (ANOVA). Significant MANOVAs were followed up with univariate $F$ tests. Mothers' scores on the four selfreport measures are shown by group in Table 3 .

A MANOVA was computed with the discipline and nurturing subscales of the PBC. No significant differences were found between mothers of children with CHD and mothers of healthy children ( $p=$ .69). Based on an ANOVA, a significant difference between groups was found for the expectations scores on the PBC $[F(1,58)=4.51, p=$ .038). As shown in Table 3, mothers of children with CHD had significantly lower expectations than mothers of healthy children. A MANOVA was computed for the three subscale scores of the Parenting Stress Index; no significant effect was found $(p=.75)$. A MANOVA including the two subscales of the ECBI and the problem behavior subscale of the BSQ was not significant $(p=.42)$. A final ANOVA with the prosocial behavior subscale of the BSQ also was not significant ( $p$ $=.30)$. 


\section{Videotaped Parent-Child Interactions}

Coding of the videotaped parent-child interaction was completed using an adapted version of the DPCICS (Eyberg, et al., 1994). This system allows observers to rate the frequency of selected behaviors for both the child and the mother in 5-minute time blocks. For the present study, nine behaviors were measured for the mothers (e.g., commands, questions, praise) and eight for the children (e.g., compliance, physical positive, whines). To remove the effects of observer bias, an individual trained and experienced in using the coding system coded the videotapes. This individual had already achieved high interobserver reliability for this observation measure, being trained to an $80 \%$ agreement criterion using other videotapes of parent-child interactions. A second trained observer rated one third (20) of the tapes to obtain an estimate of interobserver reliability. A Pearson correlation was computed between observers for each of the mother and child behaviors combined across the three phases of the directed interaction (child directed play, parent directed play, and clean up); the average inter-rater reliability coefficient was .85.

For purposes of data analyses, the 17 separate mother and child behaviors were combined across the three observations (child directed play, parent directed play, and clean up) into the following seven variables: parent positives (total number of questions, praise, and physical positives expressed by the mother); parent negatives (total criticisms, yells, whines, physical negatives, and destructive behaviors by the mother); child positives (physical positive behaviors by the child); child negatives (total number of criticism, yells, whines, physical negative behaviors, and destructive behaviors by the child); total commands by the mother; total compliant behaviors by the child; and total noncompliant behaviors by the child. This combination of separate variables was necessary because of some variables yielding zero frequencies during the videotaped observation (e.g., parent yells, parent physical negative behaviors, destructive child behaviors). The combined behavioral frequencies are shown in Table 4. A series of analyses were computed on these variables. A MANOVA with group assignment (mothers of children with $\mathrm{CHD}$, mothers of healthy children) as the independent variable, and parent positives and child positives as the dependent variables, was not significant $(p=.37)$. A

Journal of Pediatric Nursing, Vol. 17, No. 3 (June 2002): pg. 174-183. DOI. This article is @ Elsevier (WB Saunders) and permission has been granted for this version to appear in e-Publications@Marquette. Elsevier (WB Saunders) does not grant permission for this article to be further copied/distributed or hosted elsewhere without the express permission from Elsevier (WB Saunders). 
second MANOVA with two dependent variables, parent negatives and child negatives, also was not significant $(p=.41)$. Separate ANOVAs were computed and no significant differences were found between mothers of children with CHD and mothers of healthy children for parent commands $(p=.60)$, child compliance $(p=.49)$, and child noncompliance $(p=.65)$. An additional analysis was done by computing a child's compliance percentage (compliance percentage $=$ child compliance behaviors/parent commands $x 100)$. The compliance percentage for children with CHD $(M=67 \%, S D=21 \%)$ did not differ significantly $(p=.82)$ from healthy children $(M=68 \%, S D=19 \%)$.

\section{Qualitative Parenting Responses}

Each mother was asked the following question during the interview: "How is parenting (child's name) different from what you expected?" The responses were transcribed by the interviewer at the time of the home visit. An exploratory content analysis was conducted on the interview data, and themes for each of the separate interviews were identified. All themes were reviewed separately for mothers of children with CHD and mothers of healthy children; common themes for each of the groups were delineated. Supportive data, in the form of maternal quotes, were anchored to the common themes. Two independent reviewers provided content validation by reviewing the emerging themes and supportive interview data. Final content themes revisions were made. The most frequently endorsed themes and the supporting interview statements for each group of mothers are shown in Table 5. In addition to these themes, seven or more mothers of children with CHD reported using differential discipline, being concerned about comments from other parents with healthy children, feeding issues, and the children's unique temperaments. One additional theme generated by mothers of healthy children was the difficulties of balancing home and work.

\section{Discussion}

The purpose of this study was to compare the parenting practices of mothers of children with CHD and mothers of healthy children. With the exception of more mothers of children with CHD being full-time homemakers $(n=11)$ compared to mothers of healthy permission has been granted for this version to appear in e-Publications@ Marquette. Elsevier (WB Saunders) does not grant permission for this article to be further copied/distributed or hosted elsewhere without the express permission from Elsevier (WB Saunders). 
children ( $n=5)$, these two groups were highly similar on several maternal, child, and family factors known to influence child rearing, including mother's age and marital status, child's age and gender, and family's socioeconomic status. Consequently, the only important variable that distinguished the two groups was the presence or absence of child with CHD.

What emerged from the analyses of quantitative data obtained from the maternal self-report inventories and the coded, videotaped mother-child interactions were the remarkable similarities between mothers of children with CHD and mothers of healthy children. Both maternal groups reported similar nurturing and discipline practices with their young children. In addition, the parent stress levels related to child rearing did not differ between groups. These self-report findings were further validated by the videotaped parent-child interactions. Despite coding 17 different maternal and child behaviors, no significant differences for any of these behaviors were found between the two groups of mothers and their children. In fact, the only significant difference that was found between groups was that mothers of children with CHD had lower expectations for their children than mothers of healthy children. This difference in expectations also has been reported between mothers of mildly handicapped and nonhandicapped preschoolers (Tucker \& Fox, 1995). However, when interpreting this difference for the present study, it is important to note that the mean expectations scores for both groups were well within one standard deviation of the mean and thus could be considered as "normal" developmental expectations. The outcomes for the children also were similar. Children with CHD did not differ from healthy children in terms of the frequencies of their challenging or prosocial behaviors.

These findings are surprising and would have been difficult to predict based on the study's conceptual model, namely that parents and children influence each other in a reciprocal manner (Maccoby, 1992). The literature (Davis, Brown, \& Campbell, 1998) clearly shows that mothers of children with CHD experience high levels of daily stress. In response to this difficult situation, this study's conceptual model would predict that these mothers should be more likely to engage in an overly protective and more permissive parenting style

Journal of Pediatric Nursing, Vol. 17, No. 3 (June 2002): pg. 174-183. DOI. This article is @ Elsevier (WB Saunders) and permission has been granted for this version to appear in e-Publications@Marquette. Elsevier (WB Saunders) does not grant permission for this article to be further copied/distributed or hosted elsewhere without the express permission from Elsevier (WB Saunders). 
than mothers of healthy children. Yet with the exception of parental expectations, which were lower for mothers of children with CHD, these two groups of mothers appeared very similar in their parenting practices and in their experiences of parental stress related to childrearing issues. Moreover, the outcomes for their children's socialemotional development, based on the frequency of reported and observed challenging and prosocial behaviors, were unexpected. Based on our conceptual model, had we been correct in predicting a permissive parenting style among mothers with children with $\mathrm{CHD}$, it would have followed that there would be less positive outcomes for their children (Brenner \& Fox, 1999). However, based on the present data, children with CHD could not be distinguished from healthy children by their behavior.

Perhaps for this group of mothers with children with CHD, the normalization advice they received from the health care professionals had a beneficial impact on their child rearing. Based on interviews with members of the health care team, the pediatric cardiology clinic fully embraces the concept of normalization for its families. The concept of "treat your child normally" is routinely communicated to families by physicians and the nursing staff (see Moller, Neal, \& Hoffman, 1988). However, we did not collect specific data on the level of normalization advice provided to each mother or on their ability to understand and apply this principle with their children. Also, there was a range of responses on the self-report measures suggesting that some mothers of CHD children may have applied normalization strategies better than others. This conclusion is supported by recent research that suggests a continuum of family management strategies in response to a child's chronic illness ranging from thriving to floundering (Knafl, Breitmayer, Gallo, \& Zoeller, 1996).

The quantitative data collected in the present study does not tell the whole story. Mothers in both groups were asked how their parenting was different from what they had expected it to be. Qualitative analyses of their responses to this question resulted in a very different picture emerging for mothers of children with $\mathrm{CHD}$ compared to mothers of healthy children. These mothers did not expect to have a child with a serious health condition and were experiencing significant uncertainty regarding their child's future. 
These mothers responded to this situation by maintaining heightened levels of vigilance regarding their child's ongoing health status. One result was an increased reported level of stress by the mothers and other members of the family, including siblings, in the day-to-day management of the child with CHD. It is surprising and reassuring in the face of this ongoing concern that mothers were able to respond to their child in a way that produced positive parental and child outcomes. None of the children in the present study were in acute distress or hospitalized. The literature does suggest that parenting practices may be influenced by the stability of a child's chronic illness (Walker, Ford, \& Donald, 1987). Also, the normalization advice these mothers consistently received from the clinic physicians and nurses, combined with the high level of social support they reported for their parenting, may have helped them cope more effectively with some of the negative aspects associated with their children's health conditions. Clearly, more research is needed regarding the impact of this heightened state of vigilance on the mother and other aspects of family functioning (e.g., marital satisfaction, maternal depression).

\section{Limitations}

There were a number of inherent limitations with this study that does limit its generalizability. The sample only included mothers and was largely from middle to upper middle socioeconomic class. The majority of the sample was Caucasian and included mothers who were well-educated. Other known determinants of parenting practices such as marital satisfaction, maternal mental health, and level of spousal support were not studied. The children were receiving excellent health care at a pediatric cardiology clinic in a large, urban children's hospital. Consequently, the present findings are most relevant to families with similar characteristics and who are receiving similar quality health care. The study measures, including the self-report instruments and the direct observations of the mother-child interactions, were carefully selected to be technically sound and meet the purposes of the study. However, all measures, particularly self-report measures, are limited by the number of areas they can assess; also, these measures may be susceptible to a socially desirable response set. For example, the child measures used sampled primarily behavioral and emotional development. Clearly other areas of child development such as permission has been granted for this version to appear in e-Publications@Marquette. Elsevier (WB Saunders) does not grant permission for this article to be further copied/distributed or hosted elsewhere without the express permission from Elsevier (WB Saunders). 
adaptive, cognitive, language, and social development also are important but were not addressed in this study. Also, parents are unlikely to report or demonstrate on videotape child-rearing techniques that may violate social mores (e.g., yelling, spanking children). Finally, the issue of normalization surfaced as a potentially important variable in this study. However, despite this principle being well embraced by the pediatric cardiology clinic staff and routinely discussed with parents, we did not collect specific data on how much information parents received and the degree to which it influenced their child rearing philosophy or practices.

\section{Implications for Practice}

There is no question that families meet a diagnosis of CHD with considerable anxiety and concern. However, with proper attention and support by an interdisciplinary health care team, the present study's results suggest that families can cope very well with this chronic childhood illness. Specific strategies that strengthen and maintain the parenting role should be included in nursing practice (Deatrick, Knafl, \& Murphy-Moore, 1999). These include support, education and anticipatory guidance, and active listening.

\section{Support}

Social support is an important element in facilitating adaptation and adjustment to parenting a young child with CHD. The need for a comprehensive psychosocial and family assessment is indicated. This assessment should address social supports, strengths, and resources available to the family. Assisting parents to identify and develop formal and informal social support networks is a strategy that clinicians can use to help families. Family supports, church networks, and involvement with other community resources should be assessed. However, practitioners need to look beyond the "obvious" supports such as family and friends, and also consider support groups, relationships with health care providers, and on-line resources as other possible sources of support. Chat rooms, on-line support groups, and Internet access with other parents who have a child with a similar diagnosis may be helpful to some parents. 


\section{Education and Anticipatory Guidance}

Parents need to understand the specific nature of their child's CHD, including the diagnosis, prognosis, treatment plan of care, and the health care strategies needed to use within the home. The complexity of the diagnosis and treatment compounds the need for education focused on the individual needs of the child and provided in the most meaningful way to the parents. This is built on an assessment of the parents' learning style and knowledge base. At the same time, parents need consistent encouragement to raise their children as "normal" as possible including age-appropriate expectations, nurturing, and discipline strategies. Discussing normalizing strategies and helping families identify and implement these behavioral strategies are clinical applications that can be implemented by the nurse. Normalization is a complex process and clinicians need a sound understanding of the attributes of normalization.

\section{Active Listening}

The collection of the qualitative data in the present study was valuable and provided rich information regarding the parenting experience. Providing time for families to tell their stories is critical to understanding the lived experience of parenting a child with congenital heart disease. This need of mothers to tell stories and share their personal experience of parenting was also evident in the population of mothers of healthy children. An important role for the nurse is to help to slow the system down and to provide the time and opportunity for mothers to tell their stories. Through the listening of the stories, the nurse also is provided valuable information related to the stresses and strengths of the parenting experience. This can be helpful in designing strategies to support families during this life experience.

\section{Further Research}

A final implication for nurses is the need to conduct further clinical research. The normalization process needs to be further studied as it affects individual families of children with chronic illnesses. The recent work of Knafl, Breitmayer, Gallo, and Zoeller permission has been granted for this version to appear in e-Publications@Marquette. Elsevier (WB Saunders) does not grant permission for this article to be further copied/distributed or hosted elsewhere without the express permission from Elsevier (WB Saunders). 
(1996) is an example of such needed work. Further work also is needed on the heightened levels of maternal vigilance reported in this study and their short- and long-term impact on maternal health. An important related need is to identify interventions that may help mothers and fathers as they parent their young child with a chronic illness. In this time of diminished resources and cost containment, it is prudent to consider the value of nursing interventions as related to positive family outcomes. The role of the interdisciplinary team, but particularly the contributions of nurses in providing support, education, and care, cannot be discounted.

\section{Acknowledgement}

- This research served as the basis for the first author's doctoral dissertation and was supported in part by a grant from the Children's Hospital Foundation, Milwaukee, WI.

\section{Notes}

- From Marquette University, Milwaukee, WI and the University of Southern Mississippi, Hattiesburg, MS.

- Address correspondence and reprint requests to Robert A. Fox, Professor, School of Education, Marquette University, PO Box 1881, Milwaukee, WI 53201-1881; E-mail: robert.fox@marquette.edu.

\section{References}

Abidin, R.R. (1995). Parenting Stress Index Manual (3rd ed.). Charlottesville, VA: Pediatric Psychology Press.

Austin, J.K. (1991). Family adaptation to a child's chronic illness. Annual Review of Nursing Research, 9, 103-120.

Belsky, J. (1990). Parental and nonparental childcare and children's socioemotional development: A decade in review. Journal of Marriage and the Family, 52, 885-903.

Brenner, V., \& Fox, R.A. (1999). An empirically derived classification of parenting practices. The Journal of Genetic Psychology, 160, 343-356.

Clawson, J.A. (1996). A child with a chronic illness and the process of family adaptation. Journal of Pediatric Nursing, 11, 52-61.

Collins, W.A., Maccoby, E.E., Steinberg, L., Hetherington, E.M., Bornstein, M.H. (2000). Contemporary research on parenting: The case for nature and nurture. American Psychologist, 55, 218-232.

Journal of Pediatric Nursing, Vol. 17, No. 3 (June 2002): pg. 174-183. DOI. This article is @ Elsevier (WB Saunders) and permission has been granted for this version to appear in e-Publications@Marquette. Elsevier (WB Saunders) does not grant permission for this article to be further copied/distributed or hosted elsewhere without the express permission from Elsevier (WB Saunders). 
Davis, C.C., Brown, R.T., Bakeman, R., \& Campbell, R. (1998). Psychological adaptation and adjustment of mothers of children with congenital heart disease: Stress, coping, and family functioning. Journal of Pediatric Psychology, 23, 219-228.

Deatrick, J.A., Knafl, K.A., \& Murphy-Moore, C. (1999). Clarifying the concept of normalization. Image: Journal of Nursing Scholarship, 31, 209-214.

Deatrick, J.A., Knafl, K.A., \& Walsh, M. (1988). The process of parenting a child with a disability. Image: Journal of Nursing Scholarship, 13, 1521.

DeMaso, D.R., Beardslee, W.R., Silbert, A.R., \& Fyler, D.C. (1990). Psychological functioning in children with cyanotic heart defects. Journal of Developmental Behavioral Pediatrics, 11, 289-294.

DeMaso, D.R., Campis, L.K., Wypij, D., Bertram, S., Lipshitz, M., \& Freed, M. (1991). The impact of maternal perceptions and medical severity on the adjustment of children with congenital heart disease. Journal of Pediatric Psychology, 16, 137-149.

Dolgin, M.J., Phipps, S., \& Harow, E. (1990). Parental management of fear in chronically ill and healthy children. Journal of Pediatric Psychology, 15, 733-744.

Emery, J.L. (1989). Families with congenital heart disease. Archives of Disease in Childhood, 64, 150-154.

Eyberg, S.M., Bessmer, J.L., Newcomb, K., Edwards, D., \& Robinson, E.A. (1994). Dyadic parent-child interaction coding system-II: A manual (4th rev.). Corte Madera, CA: Select Press.

Eyberg, S.M., \& Ross, A.W. (1978). Assessment of child behavior problems: The validation of a new inventory. Journal of Clinical Child Psychology, 7, 113-116.

Fox, R.A. (1994). Parent Behavior Checklist. Austin, TX: ProEd. (Currently available from the author, Marquette University, School of Education, PO Box 1881, Milwaukee, WI 53201-1881; phone: 414-288-1469; email: robert.fox@marquette.edu).

Fox, R.A., Platz, D.L., \& Bentley, J.S. (1995). Maternal factors related to parenting practices, developmental expectations, and perceptions of child behavior problems. The Journal of Genetic Psychology, 156, 431441.

Goldberg, S., Simmons, R.J., Newman, J., Campbell, K., \& Fowler, R.S. (1991). Congenital heart disease, parental stress, and infant-mother relationships. Journal of Pediatrics, 119, 661-666.

Holaday, B. (1984). Challenges of rearing a chronically ill child. Nursing Clinics of North America, 19, 361-368.

Kazak, A.E. (1989). Families of chronically ill children: A systems and socialecological model of adaptation and challenge. Journal of Consulting and Clinical Psychology, 57, 25-30.

Journal of Pediatric Nursing, Vol. 17, No. 3 (June 2002): pg. 174-183. DOI. This article is (C) Elsevier (WB Saunders) and permission has been granted for this version to appear in e-Publications@Marquette. Elsevier (WB Saunders) does not grant permission for this article to be further copied/distributed or hosted elsewhere without the express permission from Elsevier (WB Saunders). 
NOT THE PUBLISHED VERSION; this is the author's final, peer-reviewed manuscript. The published version may be

accessed by following the link in the citation at the bottom of the page.

Knafl, K., Breitmayer, B., Gallo, A., \& Zoeller, L. (1996). Family response to childhood chronic illness: Description of management styles. Journal of Pediatric Nursing, 11, 315-326.

Krulik, T. (1980). Successful 'normalizing' tactics of parents of chronically ill children. Journal of Advanced Nursing, 5, 573-578.

Lobo, J.L. (1992). Parent-infant interaction during feeding when the infant has congenital heart disease. Journal of Pediatric Nursing, 7, 97-105.

Marino, B.L., \& Lipshitz, M. (1991). Temperament in infants and toddlers with cardiac disease. Pediatric Nursing, 17, 445- 448.

Maccoby, E.E. (1992). The role of parents in the socialization of children: An historical overview. Developmental Psychology, 28, 1006-1017.

Maccoby, E.E., \& Martin, J.A. (1983). Socialization in the context of the family: Parent-child interaction. In P.H. Mussen (Ed.), Handbook of Child Psychology (pp. 1-101). New York: Wiley.

Moller, J.H., Neal, W.A., \& Hoffman, W. (1988). A Parent's Guide to Heart Disorders. Minneapolis: University of Minnesota Press.

Newacheck, P.W., \& Halfon, N. (1998). Prevalence and impact of disabling chronic conditions in childhood. American Journal of Public Health, 88, 610-617.

Newacheck, P.W., Stoddard, J.J., \& McManus, M. (1993). Ethnocultural variations in the prevalence and impact of childhood chronic conditions. Pediatrics, 91, 1031-1039.

Nicholson, B., Anderson, M., Fox, R., \& Brenner, V. (in press). One family at a time: A prevention program for at-risk parents. Journal of Counseling and Development.

O'Conner, T.G., Deater-Deckard, K., Fulker, D., Rutter, M. L., \& Plomin, R. (1998). Genotype-environment correlations in late childhood and early adolescence: Antisocial behavioral problems and coercive parenting. Developmental Psychology, 34, 970-981.

Richman, N., \& Graham, P.J., (1971). A behavioral screening questionnaire for use with three-year-old children. Preliminary findings. Journal of Child Psychology and Psychiatry, 12, 5-33.

Robinson, E.A., Eyberg, S.M., \& Ross, A.W. (1980). The standardization of an inventory of child conduct problem behaviors. Journal of Clinical Child Psychology, 9, 22-28.

Sabbeth, B. (1984). Understanding the impact of chronic childhood illness on families. Pediatric Clinics of North America, 31, 47-56.

Simons, R.L., Beaman, J., Conger, R.D., \& Chao, W. (1993). Childhood experience, conceptions of parenting, and attitudes of spouse as determinants of parental behavior. Journal of Marriage and the Family, 55, 91-106.

Journal of Pediatric Nursing, Vol. 17, No. 3 (June 2002): pg. 174-183. DOI. This article is C Elsevier (WB Saunders) and permission has been granted for this version to appear in e-Publications@Marquette. Elsevier (WB Saunders) does not grant permission for this article to be further copied/distributed or hosted elsewhere without the express permission from Elsevier (WB Saunders). 
NOT THE PUBLISHED VERSION; this is the author's final, peer-reviewed manuscript. The published version may be accessed by following the link in the citation at the bottom of the page.

Svavarsdottir, E.K., \& McCubbin, M. (1996). Parenthood transition for parents of an infant diagnosed with a congenital heart condition. Journal of Pediatric Nursing, 11, 207-216.

Steinberg, L., Lamborn, S., Darling, N., Mounts, N., \& Dornbusch, S. (1994). Over-time changes in adjustment and competence among adolescents from authoritative, authoritarian, indulgent, and neglectful families. Child Development, 65, 754-770.

Tucker, M.A. \& Fox, R.A. (1995). Assessment of families with mildly handicapped and nonhandicapped preschoolers. Journal of School Psychology, 33, 29-37.

Utens, E.M., Verhulst, F.C., Erdman, R.A., Meijboom, F.J., Duivenvoorden, H.J., Bos, E., Roelandt, J.R., \& Hess, J. (1994). Psychosocial functioning of young adults after surgical correction for congenital heart disease in childhood: A follow-up study. Journal of Psychosomatic Research, 38, 745-758.

Van Dongen-Melman, J.E., \& Sanders-Woudstra, J.A. (1986). Psychosocial aspects of childhood cancer: A review of the literature. Journal of Child Psychology \& Psychiatry \& Allied Disciplines, 27, 145-180.

Walker, L.S., Ford, M.B., \& Donald, W.D. (1987). Cystic fibrosis and family stress: Effects of age and severity of illness. Pediatrics, 79, 239-246.

Journal of Pediatric Nursing, Vol. 17, No. 3 (June 2002): pg. 174-183. DOI. This article is C Elsevier (WB Saunders) and permission has been granted for this version to appear in e-Publications@Marquette. Elsevier (WB Saunders) does not grant permission for this article to be further copied/distributed or hosted elsewhere without the express permission from Elsevier (WB Saunders). 
NOT THE PUBLISHED VERSION; this is the author's final, peer-reviewed manuscript. The published version may be accessed by following the link in the citation at the bottom of the page.

\section{Appendix}

Table 1. Demographic Characteristics of Families by Study Group

\begin{tabular}{|c|c|c|c|c|}
\hline \multirow[b]{2}{*}{ Variable } & \multicolumn{2}{|c|}{$\begin{array}{c}\text { Congenital Heart } \\
\text { Disease }\end{array}$} & \multicolumn{2}{|c|}{ Healthy } \\
\hline & $\mathrm{n}$ & $\%$ & $\mathbf{n}$ & $\%$ \\
\hline \multicolumn{5}{|l|}{ Marital status } \\
\hline Married & 25 & 83.4 & 25 & 83.4 \\
\hline Not married & 5 & 16.6 & 5 & 16.6 \\
\hline \multicolumn{5}{|l|}{ Mother's education } \\
\hline High school or less & 7 & 23.3 & 5 & 16.7 \\
\hline Beyond high school & 23 & 76.7 & 25 & 83.3 \\
\hline \multicolumn{5}{|l|}{ Father's education } \\
\hline High school or less & 12 & 40.0 & 9 & 30.0 \\
\hline Beyond high school & 18 & 60.0 & 21 & 70.0 \\
\hline \multicolumn{5}{|l|}{ Mother's employment } \\
\hline Homemaker & 11 & 36.7 & 5 & 16.7 \\
\hline Working outside the home & 19 & 63.3 & 25 & 83.3 \\
\hline \multicolumn{5}{|l|}{ Father's employment } \\
\hline Professional & 10 & 33.3 & 14 & 48.3 \\
\hline Nonprofessional & 20 & 66.6 & 15 & 51.7 \\
\hline \multicolumn{5}{|l|}{ Family income } \\
\hline$\$ 50,000$ or less & 17 & 56.7 & 11 & 36.7 \\
\hline More than $\$ 50,000$ & 13 & 43.3 & 19 & 63.3 \\
\hline \multicolumn{5}{|l|}{ Children's gender } \\
\hline Male & 17 & 56.6 & 17 & 56.6 \\
\hline Female & 13 & 43.3 & 13 & 43.3 \\
\hline \multicolumn{5}{|l|}{ Children's ethnicity } \\
\hline African American & 4 & 13.3 & 4 & 13.3 \\
\hline Caucasian & 25 & 83.3 & 25 & 83.3 \\
\hline Biracial & 1 & 3.3 & 1 & 3.3 \\
\hline \multicolumn{5}{|l|}{ Birth order } \\
\hline First & 7 & 23.3 & 10 & 33.3 \\
\hline Middle & 1 & 3.3 & 5 & 16.7 \\
\hline Last & 12 & 40.0 & 13 & 43.3 \\
\hline Only & 10 & 33.3 & 2 & 6.7 \\
\hline \multicolumn{5}{|l|}{ Parenting classes } \\
\hline Yes & 7 & 23.3 & 6 & 20.0 \\
\hline No & 23 & 76.7 & 24 & 80.0 \\
\hline \multicolumn{5}{|l|}{ Amount of social support } \\
\hline Low & 1 & 3.3 & 4 & 13.3 \\
\hline Medium & 6 & 20.0 & 40 & 33.4 \\
\hline High & 23 & 76.7 & 16 & 53.3 \\
\hline
\end{tabular}

Journal of Pediatric Nursing, Vol. 17, No. 3 (June 2002): pg. 174-183. DOI. This article is @ Elsevier (WB Saunders) and permission has been granted for this version to appear in e-Publications@Marquette. Elsevier (WB Saunders) does not grant permission for this article to be further copied/distributed or hosted elsewhere without the express permission from Elsevier (WB Saunders). 
NOT THE PUBLISHED VERSION; this is the author's final, peer-reviewed manuscript. The published version may be accessed by following the link in the citation at the bottom of the page.

Table 2. Health-Related Characteristics of Children with Congenital Heart Disease

\begin{tabular}{|l|c|c|c|c|c|}
\hline \multicolumn{7}{|c|}{ Variable } & $\mathbf{n}$ & $\%$ & $\mathbf{M}$ & SD $^{*}$ & Range \\
\hline Time of diagnosis & 2 & 6.7 & & & \\
\hline Fetal diagnosis & 14 & 46.7 & & & \\
\hline At birth & 10 & 33.3 & & & \\
\hline First month of life & 4 & 13.3 & & & \\
\hline After first month of life & 2 & 6.7 & & & \\
\hline Cardiologists' perception of medical severity & \multicolumn{5}{l|}{} \\
\hline 3-Moderate & 20 & 66.6 & & & \\
\hline 4-Marked & 8 & 26.7 & & & \\
\hline 5-Severe & & & 2.37 & 1.15 & $0-5$ \\
\hline Total hospitalizations & & & 30.57 & 22.10 & $0-106$ \\
\hline Total days in hospital & & & 2.10 & 1.15 & $0-5$ \\
\hline Cardiac operations & & & 1.57 & 1.16 & $0-5$ \\
\hline Cardiac catherizations & & & 12.50 & 4.82 & $4-28$ \\
\hline Outpatient visits since diagnosis & & &
\end{tabular}

${ }^{*} \mathrm{SD}=$ Standard deviation

Table 3. Summary Scores for Self-Report Measures by Study Group

\begin{tabular}{|l|c|c|c|c|}
\hline \multirow{2}{*}{ Variable } & \multicolumn{2}{c|}{$\begin{array}{c}\text { Congenital Heart } \\
\text { Disease }\end{array}$} & Healthy \\
\cline { 2 - 5 } & M & SD $^{*}$ & M & SD $^{*}$ \\
\hline Parent behavior checklist & 45.16 & 9.99 & 50.53 & 9.56 \\
\hline Expectations & 40.43 & 10.02 & 42.43 & 7.91 \\
\hline Discipline & 55.53 & 11.78 & 56.03 & 11.48 \\
\hline Nurturing & 26.00 & 6.65 & 24.77 & 8.50 \\
\hline Parenting stress index & 18.10 & 5.98 & 16.77 & 4.21 \\
\hline Parental distress & 26.50 & 6.38 & 26.03 & 8.07 \\
\hline Parent-child dysfunction & 100.17 & 28.69 & 99.13 & 25.59 \\
\hline Difficult child & 10.30 & 16.70 & 9.20 & 12.61 \\
\hline Eyberg child behavior inventory \\
\hline Intensity & \multicolumn{5}{|l|}{} \\
\hline Frequency & 23.13 & 4.40 & 21.77 & 3.65 \\
\hline Behavior screening questionnaire & 5.12 & 44.20 & 4.48 \\
\hline Problem behaviors & 44.17 & \\
\hline Prosocial behaviors
\end{tabular}

${ }^{\star} \mathrm{SD}=$ Standard deviation

Journal of Pediatric Nursing, Vol. 17, No. 3 (June 2002): pg. 174-183. DOI. This article is @ Elsevier (WB Saunders) and permission has been granted for this version to appear in e-Publications@Marquette. Elsevier (WB Saunders) does not grant permission for this article to be further copied/distributed or hosted elsewhere without the express permission from Elsevier (WB Saunders). 
NOT THE PUBLISHED VERSION; this is the author's final, peer-reviewed manuscript. The published version may be accessed by following the link in the citation at the bottom of the page.

Table 4. Combined Maternal and Child Behaviors from Videotaped Interactions

\begin{tabular}{|l|c|c|c|c|}
\hline \multirow{2}{*}{\multicolumn{1}{|c|}{ Variable }} & \multicolumn{2}{c|}{$\begin{array}{c}\text { Congenital } \\
\text { Heart Disease }\end{array}$} & \multicolumn{2}{c|}{ Healthy } \\
\cline { 2 - 5 } & M & SD $^{*}$ & M & SD $^{*}$ \\
\hline Parent positive & 60.13 & 4.98 & 59.53 & 4.98 \\
\hline Parent negative & 1.83 & 0.49 & 0.93 & 0.49 \\
\hline Child positive & 0.00 & 0.03 & 0.06 & 0.03 \\
\hline Child negative & 2.77 & 1.03 & 2.07 & 1.03 \\
\hline Parent commands & 27.97 & 3.12 & 25.67 & 3.12 \\
\hline Child compliance & 17.30 & 1.64 & 15.70 & 1.64 \\
\hline Child noncompliance & 7.00 & 1.41 & 6.10 & 1.41 \\
\hline
\end{tabular}

*SD = Standard deviation

Journal of Pediatric Nursing, Vol. 17, No. 3 (June 2002): pg. 174-183. DOI. This article is (C) Elsevier (WB Saunders) and permission has been granted for this version to appear in e-Publications@Marquette. Elsevier (WB Saunders) does not grant permission for this article to be further copied/distributed or hosted elsewhere without the express permission from Elsevier (WB Saunders). 
NOT THE PUBLISHED VERSION; this is the author's final, peer-reviewed manuscript. The published version may be accessed by following the link in the citation at the bottom of the page.

\section{Table 5. Most Frequently Endorsed Interview Themes and Supporting Statements for Mothers of Children with Congenital Heart Disease (CHD) and Mothers of Healthy Children}

\begin{tabular}{|c|c|c|}
\hline Interview Theme & $\begin{array}{l}\text { Number of } \\
\text { Respondents }\end{array}$ & Supporting Maternal Statements \\
\hline \multicolumn{3}{|c|}{ Mothers of Children with CHD } \\
\hline $\begin{array}{l}\text { (1) The } \\
\text { unexpected }\end{array}$ & 19 & $\begin{array}{l}\text { We didn't learn about his condition until he was } 1 \frac{1}{2} \\
\text { weeks. Then we found out about his heart and it was a } \\
\text { complete shock. }\end{array}$ \\
\hline (2) Vigilance & 19 & $\begin{array}{l}\text { We are not comfortable leaving her overnight. I have not } \\
\text { slept away from my kids for } 4 \text { years. }\end{array}$ \\
\hline (3) Uncertainty & 19 & $\begin{array}{l}\text { He sleeps with us each night. I am afraid he will stop } \\
\text { breathing. There is always that fear. }\end{array}$ \\
\hline $\begin{array}{l}\text { (4) Positive } \\
\text { outlook }\end{array}$ & 14 & $\begin{array}{l}\text { We try to live each day fuller now, we don't take a day for } \\
\text { granted. }\end{array}$ \\
\hline (5) Normalization & 11 & $\begin{array}{l}\text { I would say I do not treat him differently. Just make sure } \\
\text { he gets his medicine. I watch his activity level, if he is out } \\
\text { of breath or turning blue. Otherwise, I treat him like a } \\
\text { normal kid, he is a normal kid. }\end{array}$ \\
\hline (6) Stress & 10 & $\begin{array}{l}\text { It's a lot more stressful on the whole family. I feel bad for } \\
\text { our older daughter. I think she had to grow up fast. }\end{array}$ \\
\hline \multicolumn{3}{|c|}{ Mothers of Healthy Children } \\
\hline (1) Temperament & 22 & $\begin{array}{l}\text { He has a strong personality and he will keep asking until } \\
\text { we give in. }\end{array}$ \\
\hline (2) Strains & 13 & $\begin{array}{l}\text { I always thought it (parenting) would be a lot of work and it } \\
\text { is. But I am surprised at the amount of energy it takes. }\end{array}$ \\
\hline (3) Rewards & 11 & $\begin{array}{l}\text { I knew we would enjoy parenthood, but I didn't realize all } \\
\text { the rewards and special times that go along with it. }\end{array}$ \\
\hline (4) Expectations & 9 & $\begin{array}{l}\text { Hardest job on earth. It really is; nothing could have } \\
\text { prepared me for it. }\end{array}$ \\
\hline (5) Discipline & 9 & $\begin{array}{l}\text { I didn't expect to feel inadequate, not knowing if I am doing } \\
\text { the right thing. Like when I discipline her. }\end{array}$ \\
\hline (6) Comparisons & 7 & $\begin{array}{l}\text { I can compare him with my other child. He is much more } \\
\text { active and independent. }\end{array}$ \\
\hline
\end{tabular}

Journal of Pediatric Nursing, Vol. 17, No. 3 (June 2002): pg. 174-183. DOI. This article is C Elsevier (WB Saunders) and permission has been granted for this version to appear in e-Publications@Marquette. Elsevier (WB Saunders) does not grant permission for this article to be further copied/distributed or hosted elsewhere without the express permission from Elsevier (WB Saunders). 